\title{
Front-Line Employees' Recognition And Empowerment Effect On Retail Bank Customers' Perceived Value
}

\author{
Vida Škudienė, ISM University of Management and Marketing, Lithuania \\ Dallas D. Everhart, University of Northern Colorado, USA \\ Karolina Šlepikaite, ISM University of Management and Economics, Lithuania \\ James Reardon, University of Northern Colorado, USA
}

\begin{abstract}
Understanding how front-line bank employee recognition and empowerment impacts customer value is an important issue for the banking industry. Retail banking customers perceive little difference in services as competition has created more choices. When banks develop new products, they are easily duplicated by the competition. Banks can gain a competitive advantage by understanding the interrelationships that impact customer's perceived value. The major providers of customer perceived value in retail banking are front-line employees. This research aims to better understand these interrelationships and examine how front-line retail bank employee recognition and empowerment relate to retail bank customer perceived value. Customer's perceived value is defined in terms of relationship, social, emotional, service and empowerment. Survey findings illustrate that retail banks should concentrate more on employee recognition and empowerment to impact customers' perceived value. According to the findings of the survey, front-line employee recognition and empowerment has a positive impact on customer's perceived value.
\end{abstract}

Keywords: Customer Service; Employee Recognition; Employee Empowerment; Customer Perceived Value; Relationship Value; Social Value; Emotional Value; Service Value; Empowerment Value

\section{INTRODUCTION}

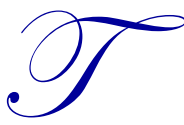

he retail banking sector has experienced dramatic change in the past few years due to increased competition. Customers perceive little difference in products and services and new offerings are quickly matched by competitors with similar prices. Subsequently, banks should examine how customers perceive value. This research measures customers' perceived value as relationship, social, emotional, service and empowerment (Christopher, 2001).

Recognition of the importance of the employee-customer interface in creating customer value has prompted the interest of many researchers. According to Barnes and Howlett (1998) "Research suggests that relationships a company develops with customers is largely determined by front-line employees' performance" (p. 21). According to Thomas and Velthouse (1990) front line employees who are empowered have more motivation to sell products and improve quality of the service, and improve customer service, creating value.

The research aim is to disclose the linkage between front-line employee recognition and empowerment to retail bank customer perceived value and provide recommendations how to enhance customer perceived value. The research question is "How do front line employee recognition and empowerment effect retail bank customer perceived value?" 
The Research objectives are the following:

- To conduct theoretical and empirical analysis to identify the interrelationships of front line employee recognition and empowerment on customer perceived value;

- $\quad$ To design conceptual employee recognition, empowerment and customer perceived value relational model;

- $\quad$ To perform empirical research in order to test the designed conceptual model;

- $\quad$ To provide recommendations on how to enhance retail bank customer perceived value.

\section{RESEARCH PROBLEM DEFINITION}

The role of retail banking has changed radically in recent years. Retail banking customers perceive little difference in services and due to competition; new offerings are quickly matched by competitors. Today's retail banking customers have more choices for their needs in banking service driving the industry to understand and assess customer value and expectations.

Many retail banks have invested in customer relationship management but "most financial entities still have a lot of work ahead of them to identify the information that is really relevant and use it effectively in the enhancement of value for their customers" (Samad, 2007, p. 259). The banks have taken more interest in creating customer perceived value, but at the same time they experience customer dissatisfaction. It is more important than ever to know how to create and enhance customer value in retail banking. For many banks the term "customer value is used solely to refer to the value that the customer generates for them, rather than the value that they can offer to their users" (Roig 2006, p. 271). By identifying the interrelationships of perceived value created by front-line employees the banks can make a positive impact on perceived customer value. For the retail banking sector it is important to realize which dimensions create customer perceived value and have the highest impact for customers.

The major supplier of customer value in the banking sector is front-line employees. Banks devote sufficient attention to the selection of front-line employees and training them because they interact directly with customers. These employees are the ones who answer customers' questions, help to customers find what they are seeking and meet their needs. "Front line employee perceptions of how they are treated by the bank will influence what they believe the company will do for the customer" (Samad, 2007, p. 163). Loveman (1998) found that "front-line employees are the primary resource through which service businesses can gain a competitive advantage" (p. 24). According to Loveman "there is problem in many service industries because the skills needed to provide service quality usually are not in alignment with the skills usually found in front-line positions" (p. 28).

According to Carter (2009), two key dimensions that affect employees are recognition and empowerment. Recognition helps to motivate employees to achieve higher results. Empowered employee can make decisions quickly and make good impression on customers. Thus, empowered front-line employees' are motivated in their work and perform successfully. In this thesis the aim is to better understand these interrelationships and examine how front line retail bank employee recognition and empowerment relate to retail bank customer perceived value.

The main hypotheses that will be tested in empirical research are presented below:

H1: Front line employees' recognition has a positive relationship with customers' perceived value

H2: Front line employees' empowerment has a positive relationship with customers' perceived value 


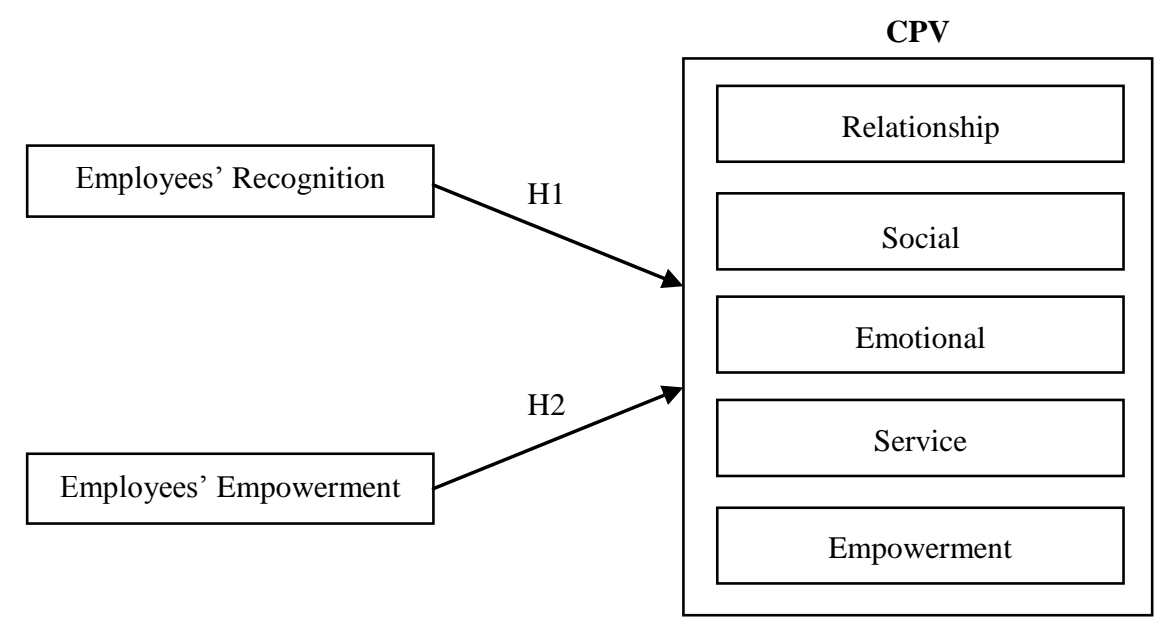

Figure 1: Research Model

\section{LITERATURE REVIEW}

The literature on employee recognition and empowerment is extensive. The following literature review provides a foundation for the research on correlation to customer's perceived value. Customer's perceived value literature is also extensive providing a solid foundation for designing the following methodology.

\section{Employee Recognition}

According to Saunderson (2004), recognition is a process which "includes giving praise, awards and ceremonies" (p. 263). Luthans (2000) describes recognition as a "process which is easy to do and inexpensive". Both authors define recognition as a process. According to London and Higgot (1997) the recognition process consists of the eight main elements: "categories for awards, nominations, review of nominations, recognitions of successful nominations, review of successful nominations, final selection, awards and annual quality award" (p. 331). Recognitions as a process can come in a few formats such as rewards, pay raises or promotions (Hopkins, 1995).

According to Nelson (2001) the characteristics which create powerful employee recognition programs include immediate recognition from the supervisor, valued and for real accomplishment. According to London and Higgot (1997) recognition as a process gives a statement to front line employees of the company values. According to Saunderson (2004) a lack of recognition is one of the main reasons why a good employee quits the job.

\section{Employee Empowerment}

Spreitzer (1995) defined empowerment as a "process of orienting individuals to think, behave, and take action in an autonomous way" (p. 1451). It helps employees to own their input and take responsibility for all results. Employee empowerment can be perceived in two ways. First, as a set of managerial practices aiming at increasing employees responsibilities and secondly as an individual work orientation (Spreitzer, 1995). Empowerment has been defined as to "authorize and give power". Wilkinson (1998) found that empowerment should be used in terms of a separate model to assist for trust and collaboration. Pastor (1996) defines empowerment in duration of its active interaction. The authors defined empowerment as a concept that relates to employee's strengths and competencies, helping social change. Empowerment of workers helps the company to compete successfully in the market.

Spreitzer (1995) found four characteristics which influence empowerment: defined knowledge, communication, trust and incentives. Knowledge helps employees to understand that their work is important. Trust could exercise self-determination, and incentives may boost employees' motivation. According to Spreitzer (1995) there are the three empowerment aspects of intrinsic task motivation: 
1) Autonomy, like a sense a freedom of employees in making decisions about them work, and the feeling of results of responsibility for these decisions.

2) Competence, like a belief in a power to accept decision successfully.

3) Meaningfulness, like a perceived value of employees to personal beliefs and values.

There is the "multi-dimensional empowerment perspective which views the role of managers and leaders" (Lee and Koh 2001, p. 91). The authors suggested that to "empower smoothly it is necessary to view the role of managers and leaders, as they have important impact upon the psychological sense held by the workers" (p. 93). According to Johnson (1994) management should give employees freedom to do their job. Therefore the authors viewed the importance of relationship as an interactive process. According to Honold (1997) management is responsible for finding a goal which they share with employees. The author found that management could focus on whole employees' empowerment as well as individual empowerment if the company trusts cohesive teams.

According to Spreitzer (1995) front line employees should be empowered to make an immediate decision or they may lose an opportunity. Conger and Kanungo (1988) found that "power is often reallocated by moving control so front line employees have the authority to make and implement their own decisions" (p. 478). Mullins and Peacock (1991) found that "empowered front line employees have a greater sense of job satisfaction and motivation, as they feel more involved in the achievement of company goals" (p. 51).

\section{Customer Perceived Value}

According to Roig (2006) and Loveman (1998) the definition of customer value is a difference between total customer value that customer get from a product or service in organization and total customer cost incurred from assessing and using that product or service. This value can be perceived only by customers who use the product or receive the service. Loveman (1998) defined customer value as a comparison of weighted 'get' feature with 'give' features. Christopher (2001) found that modern marketing managers are focusing on providing value for customers as the key to success for organizations. According to the authors there are two main approaches which could help to measure the level of perceived value. Cronin, Michael and Hult (2000) defined an approach of perceived value as the structure of benefits received and sacrifices made. The customer benefits include the perceived quality of the product and psychological benefits. This could include economic, social, relational benefits. Sacrifices can be in the form of monetary or non-monetary prices such a time, risk and convenience (Christopher, 2001). According Roig (2006) the second approach shows customer perceived value as a multidimensional structure. Authors, who explore the concept of value as a multidimensional construct, found that at least two dimensions can be differentiated: functional and emotional.

Sheth, Newman and Gross (1991) defined perceived value as a multidimensional structure with five values: social, emotional, functional, epistemic and conditional. Social value shows relationship with the social environment. Emotional value, according to the author, is a feelings obtained by the experience. "Functional value is perceived utility of the attributes of the services" (Sheth, Newman and Gross 1991, p. 163). Epistemic value described as a capacity of the service to satisfy the desire of knowledge. The last conditional value refers to situational factors.

Furthermore Roig (2006) found that customer perceived value results from integration between functional value, emotional value and social value. Functional value can be found through logical and economical evaluation from customer based on price and quality of a service. Emotional value driven by internal factors and social value is driven by external factors.

Based on above definitions there are five chosen customers' perceived value:

- Relationship value which describes the customers' relationship with the front line employees from experiences. Relationship value is common in retail banking services, because there is a great deal of contact between front line employees and customers. This kind of value creates trust between customers and employees.

- Social value that is received from associations with positively or negatively stereotyped groups or communities. Both social and organization value can be important to create value. According to Sheth, 
Newman and Gross (1991) "social value is the acceptability at the level of the customer's relationship with their social environment" (p. 164).

- $\quad$ Emotional value represents the capacity of a service or product to create feelings and is measured of a set of feelings toward its object. Roig (2006) described emotional value in "two dimensions: pleasantness or unpleasantness and arousal or quietness" (p. 271). Emotional reactions created by contact with employees could influence customers' decision to buy product or service.

- Service value is defined as the difference between consumer's perception and expectations". According to Sheth, Newman and Gross (1991) perceived service value is the customer's "comparison of all benefits taken from the purchase and use of a service with costs" (p. 167). McDougall and Levesque (2000) found that perceived service value could be one of the main dimensions of an organization competitive advantage.

- Empowerment is a "management tool which helps organizations' create an environment" (Wilkinson 1998, p. 40). As a process, "empowerment needs for customers to gain control over issues that trouble them, including a chance to practice skills and exert control over their decision making. He found that empowerment as an outcome is subjective" (p. 40).

\section{Relationship Value}

According to Peterson (1995) relationship value refers to the customer perceived value of the customer's relationship with the front line employee created by emotional aspects. In these aspects could be included sympathy, friendship, trust and other personal characteristics. Personal characteristics have strong impact on the customer value of an interaction (Peterson, 1995). According to the author this type of customer value seems to be common in retail banking services were employees have contact with customers. A good relationship in a financial institution creates trust between customers and employees.

\section{Social Value}

Sheth, Newman and Gross (1991) described social value as a value that is received from an association with positively or negatively stereotyped groups or communities. According to the author if employees and customers have similar education and intellectual backgrounds, these aspects are perceived as positive value drivers. Both social and organization value can be important to create value. According to Sheth, Newman and Gross (1991) "social value is the acceptability at the level of the customer's relationship with the social environment" (p. 160). Social value is more intangible and can be measured as value judged by customer feelings to purchasing service. Social value is driven by external factors. Sheth, Newman and Gross (1991) showed that products or services have social value when it has a relationship with social groups. Social value related to social image. Sheth, Newman and Gross (1991) found that consumers' determination of value has high relationship with social groups, economic environment and culture.

\section{Emotional Value}

Sheth, Newman and Gross (1991) described that "emotional value represent the capacity of a service or product to create feelings and is measured of a set of feelings toward its object" (p. 159). According to author a product or service has emotional value only when it can change customers' feelings. Authors described emotional value in two dimensions: pleasantness or unpleasantness and arousal or quietness. According to Sheth, Newman and Gross (1991) emotional value could be created by an atmosphere of employees contact in the service environment. Emotional reactions created by contact with employees could influence customers' decision to buy product or service. Anderson, Fornell and Rust (1997) found that employees contact with customers strongly created emotional reactions. They found that positive emotional reaction could create consumers associations with loyalty, nostalgia and excitement. But on the other hand negative emotional reaction could create fear, anger and a sense of injustice. "Emotional or pleasantness value could give a stronger favourable emotional reaction" according to Sheth, Newman and Gross (p. 163). In the banking industry employees who show individual worry about the customer, affect a favourable emotional reaction. 


\section{Service Value}

Sawhney and Kotler (2001) defined perceived service quality as provision relating to the advantage of the service. Authors linked the definition of service quality to the concepts of perception and expectations. McDougall and Levesque (2000) found that "perceived service value could be one of the main dimensions of a organization competitive advantage. In the research authors found that higher perceived service quality leads to higher perceived service value" (p. 402). Similar Petrick (2004) found that "perceived service quality is the best predictor of perceived service value" (p. 401).

\section{Empowerment}

Cook and Macaulay (1996) defined empowerment as "A process for customers to gain control over issues that trouble them, including a chance to practice skills and exert control over their decision making" (p. 10). According to Ramani and Kumar (2008) "customer empowerment is important for individual and organizational interactions". Sawhney and Kotler (2001) found that consumer empowerment depends on:

- $\quad$ Number and quality of the value propositions that are available in the market;

- $\quad$ Customer market knowledge;

- $\quad$ Customer ability to search for and gather new market information;

- $\quad$ Customer ability to take advantage of alternative value propositions.

According to Ramani and Kumar (2008) "empowered consumers could be expected to demonstrate their power during selection process, either by choosing one value proposition or by rejecting offer. According to Wilkinson (1998) customer empowerment affects organizations internal new product development process as reflected in the product and the relationship between the organizations and its empowered customers. According to the author, there are "strong arguments indicating that customer empowerment in new product development enables organizations to develop better products and at the same time to reduce costs and risks if customer in a given domain is willing and able to deliver valuable input" (p. 40).

\section{HYPOTHESES}

It is evident the correlation between employee recognition and empowerment to customer's perceived value is an important issue for retail banking. Many studies have examined the different employee perceptions and customer issues. We will focus on the role of front line employees in retail banking to build customer perceived value.

\section{Front Line Employee Recognition}

An important factor for successful organizations is employee recognition (Bowers, Martin and Luker, 1990). One of the important challenges facing management is how to create an environment within which employees feel recognized. According to Bowers, Martin and Luker (1990) there are four important factors that must be shared with employees:

\section{- Information about the organization performance;}

- Reward based on the organization's performance;

- Knowledge that enables employees to understand and contribute to organizational performance;

- $\quad$ Power to make decisions that influence organizational direction and performance.

According to the Bowers, Martin and Luker (1990) "there is increasing recognition of the importance of considering employees as internal marketing to appeal and serve rather than only employees to be tapped" (p. 58). Recognition is one of the main keys to treating employees as customers (Roig, 2006). In this way organizations understand that customers should be treated with respect. This helps for organizations to handle employees, and enhance customer value. The attitude of organizations may be communicated through recognition. According to 
Bowers, Martin and Luker (1990) "Not only the individual employee motivated through recognition, but that employee's co-workers are provided with an illustration of that the organization considers being exemplary performance."

London and Higgot (1997) mentioned that regularly applicable recognitions programs give management a "powerful tool to influence workers to live the firm's values and focused on mission that influence customer perceived value and there is growing need for recognition expressed by today's employees" (p. 331). According to Hopkins (1995) employee recognition is one of the most important criteria for customer value. Employee recognition equally important and powerful for two parties: employees and customers. Therefore, the following hypothesises are raised:

H1: Front-line employees' recognition has a positive relationship with customers' perceived value

H1a: Front-line employees' recognition has a positive relationship with customers' relationship value

H1b: Front-line employees' recognition has a positive relationship with customers' social value

H1c: Front-line employees' recognition has a positive relationship with customers' emotional value

H1d: Front-line employees' recognition has a positive relationship with customers' service value

H1e: Front-line employees' recognition has a positive relationship with customers' empowerment

\section{Front Line Employee Empowerment}

According to Loveman (1998) empowerment is a crucial aspect for customer perceived value. Employees' need to be empowered over the service performance in order to satisfy and be responsive to customer needs. Thus, employee empowerment increases customer perceived value. Employees who are empowered have more motivation to sell products and improve quality of the service and improve customer perceived value (Spreitzer, 1995). Therefore the relationship between "customer value and services depends on increasing the quality of banking service since customers prefer to participate in producing banking service and products" (Wilkinson 1998, p. 51). This allows employees to identify customers' needs and enhance of customer empowerment.

According to Samad (2007) empowered employees create good results and contribute to the development of organization. The author defined empowerment as a concept that relates employee's strengths and competencies to helping social change. Sheth, Newman and Gross (1991) stated that "product or service has social value when it has a relationship to social groups and social image" (p. 168). Therefore, Samad (2007) found that consumers' determination of value has a high relationship with social groups, economic environment and culture. Author defined that social value has strong relations with symbolic value. For the social value, selecting a brand or product could improve customer's self-image (Samad, 2007).

Employee empowerment helps organization to compete successfully in the market and create customer value (Samad, 2007). Employees should be empowered to make an immediate decision to improve quality of the service for the customers (Wilkinson, 1998; Carter, 2009; Samad, 2007). Empowerment is one of the most important variables for the front-line employees. According to Wilkinson (1998) empowerment is crucial for customer value. Front-line employee empowerment is one of the dimensions on research model that impact customer value. Based on this, the following hypothesis is raised:

H2: Front-line employees' empowerment has a positive relationship with customers' perceived value

H2a: Front-line employees' empowerment has a positive relationship with customers' relationship value

H2b: Front-line employees' empowerment has a positive relationship with customers' social value

H2c: Front-line employees' empowerment has a positive relationship with customers' emotional value

H2d: Front-line employees' empowerment has a positive relationship with customers' service value

H2e: Front-line employees' empowerment has a positive relationship with customers' empowerment

\section{METHODOLOGY}

To identify the impact of front line employee recognition and empowerment on retail bank customer's perceived value it is necessary to test the correlation. The quantitative research focuses on analyzing the relationship 
between front line employee recognition; empowerment and retail bank customer's perceived value. According to the aim of the research and its objectives survey strategy has been chosen.

The subjects included 30 front line employees who have their own customer base. Employees were asked to complete a questionnaire at a convenient time and distribute questionnaires to their customers. The questionnaire included rating questions with a Likert scale of 1 to 10 , where " 1 " means "Disagree absolutely" and " 10 " means "Agree absolutely". These broad criteria of assessment allow evaluating concrete respondent opinions (Kumar, 1996).

Table 1: Measures

\begin{tabular}{|c|c|c|}
\hline Construct & Item Mean & Construct Reliability \\
\hline Employee Recognition (Moncar, Zhao and Kay, 2008) & & $\alpha=.793$ \\
\hline Employees are recognized and get citations for well-done jobs & 7.93 & \\
\hline Our compensation and benefits system is well known to everyone & 8.53 & \\
\hline Employees who do jobs well are always commended by managers & 8.57 & \\
\hline Employee Empowerment (Melhem, 2003) & & $\alpha=.669$ \\
\hline I have some freedom in accomplishing my work & 8.07 & \\
\hline I can independently make decisions related to my job & 7.73 & \\
\hline In order to help my customers I do much more than is stated in my position & 8.80 & \\
\hline \multicolumn{3}{|l|}{ Customer Perceived Value $(C P V)$} \\
\hline CPV - Relationships Value (Roig, Garcia, Tena and Monzonis, 2006) & & $\alpha=.865$ \\
\hline Bank personnel do their job well & 8.35 & \\
\hline Bank personnel's professional knowledge is excellent & 8.57 & \\
\hline Information provided by bank personnel is topical and useful & 8.09 & \\
\hline CPV - Emotional Value (Roig, Garcia, Tena and Monzonis, 2006) & & $\alpha=.937$ \\
\hline I am happy with the banks services & 8.30 & \\
\hline I feel relaxed while communicating with bank personnel & 8.79 & \\
\hline I trust in the bank's personnel & 8.31 & \\
\hline CPV - Service Value (Roig, Garcia, Tena and Monzonis, 2006) & & $\alpha=.811$ \\
\hline The quality of the banks services is very good & 8.09 & \\
\hline Banks services meet my expectations & 8.17 & \\
\hline The level of quality is better than compared to other banks & 8.01 & \\
\hline CPV - Social Value (Roig, Garcia, Tena and Monzonis, 2006) & & $\alpha=.861$ \\
\hline My family agrees that I should use this bank's services & 8.22 & \\
\hline The fact that I bank here looks good to people that I know & 8.11 & \\
\hline This bank is considered prestigious at a social level & 8.28 & \\
\hline CPV - Empowerment Value (O'Cass, Liem Viet, 2011) & & $\alpha=.696$ \\
\hline My needs and expectations impact the final outcome & 7.37 & \\
\hline Bank employees consult me about the design of new products & 5.28 & \\
\hline My opinion is important for bank employees & 7.45 & \\
\hline
\end{tabular}

\section{Analysis and Results}

Structural Equitation Modeling (SEM) using LISREL 8 was used to estimate the model in Figure 1 above. As would be expected, the overall Chi-Squared statistic was significant. However, the rest of the overall model fit measures show a reasonable conformance of the data to the model. The Root Mean Square Error of Approximation (RMSEA) (0.012) was slightly above the 0.08 cutoff values suggested by Browne and Cudeck (1993). This is not surprising given that CPV tend to be highly interrelated and perhaps even a second order factor. The absence of modeling CPV as a second order factor, which would have not allowed the hypotheses to be tested, created measurement error in the model. In addition, the CFI (.92), NNFI (.91), and IFI (0.92) were above the commonly recommended 0.90 limit (Lichtenstein et al., 1992).

\section{EMPIRICAL RESEARCH RESULTS}

The following tables show the results of the survey questions distributed to bank front-line employees and customers. The response to employee recognition and empowerment is shown individually and the average response is also identified. 
Table 2: SEM Hypotheses Results

\begin{tabular}{|l|c|c|}
\hline \multicolumn{1}{|c|}{ Hypothesis/Path } & t-value (estimate) & Results \\
\hline H1: Employee Recognition & & \\
\hline a. CPV Relationship & $2.16(8.74)^{*}$ & \\
b. CPV Social Value & $2.14(7.09)^{*}$ & Supported \\
c. CPV Emotional Value & $2.14(8.77)^{*}$ & \\
d. CPV Service Value & $2.13(8.24)^{*}$ & \\
e. CPV Empowerment & $2.02(4.87)^{*}$ & \\
\hline H2: Employee Empowerment & & \\
\hline a. CPV Relationship & $2.12(8.60)^{*}$ & \\
b. CPV Social Value & $2.09(6.93)^{*}$ & \\
c. CPV Emotional Value & $2.10(8.63)^{*}$ & \\
d. CPV Service Value & $2.11(8.15)^{*}$ & \\
e. CPV Empowerment & $1.92(4.61)^{*}$ & \\
\hline
\end{tabular}

It was found that all estimates are statistically significant (one tailed test). The calculated estimates show that significant relationships exist between recognition of employees and relationship value (2.16), social value (2.14), emotional value (2.14), service (2.13) and empowerment (2.02). Significant estimates exist between employee empowerment and relationship value (2.12), social value (2.09), emotional value (2.10), service value (2.11) and empowerment (1.92).

Hypothesis 1: Employee recognition was measured to test the correlation between customer's perceived value and employee recognition. It can be stated that front-line employees' recognition has a positive relationship with customers' perceived value.

Hypothesis 2: Employee empowerment was measured to test the correlation between customer's perceived value and employee recognition. It can be stated that front-line employees' empowerment has a positive relationship with customers' perceived value.

Hypothesis H1a, b, c, d, e, and H2a, b, c, d, e, were also confirmed.

\section{DISCUSSION}

Results indicate the strongest positive estimate exists between employee recognition and customer's perceived relationship value. The results also indicate the least relationship between employee empowerment and customers perceived empowerment value. Reviewing both employee recognition and employee empowerment findings it appears customer perceived value as measured by relationship has the highest correlation. Customers' perceived value measured as empowerment had the lowest relationships with employee recognition and empowerment.

\section{CONCLUSIONS}

Based on the analysis of literature and empirical research on the estimate of front line employee recognition and empowerment on retail bank customer perceived value; the following conclusions are made:

1. The literature review indicates that over the last ten years there are important changes in the retail banking sector. The main cause of these changes has been increasing competition resulting in similar services and products. Customers perceive little difference in the services and products offered by banks. How customers perceive value has become a management focus for banks.

2. Empirical research showed a positive correlation between employees' recognition and empowerment to customers' perceived value. Employee recognition consistently indicated a higher correlation to the individual elements of customer's perceived value compared to employee empowerment. Both employee recognition and empowerment can be useful strategies for retail banks as they compete for customers. The difference between employee recognition and empowerment is relatively small and either approach could be appropriate depending on other factors. 
3. In order to provide the value customers' appreciate, bank management should be involved in value creation. Retail bank management could enhance customer relationship, social, emotional and empowerment perceived value through employee recognition and empowerment.

4. Employee recognition may provide a greater opportunity to increase customer's perceived value compared to employee empowerment. However, the difference between the employee recognition and empowerment on estimates of influence on customer's perceived value does not appear to be large. If required to focus on a single measure it appears that employee recognition would have the greatest impact on customer's perceived value as defined by relationship. If forced to decide between an employee recognition program or an employee empowerment program, the results suggest employee recognition have the greater influence on customer's perceived value.

5. Employee empowerment also has a positive relationship with customer's perceived value. Customer's perceived relationship shows the highest connection with employee empowerment indicating the importance of empowerment and relationships.

6. Retail banking would be advised to enhance both employee recognition and empowerment programs to positively influence customer's perceived value. The differences between employee recognition and employee empowerment does not appear to be major. Improving both programs could be a successful strategy influencing customer's choice of banking options in a competitive market.

\section{AUTHOR INFORMATION}

Dr. Vida Škudienė is the Professor of Marketing and Organizational Behaviour at ISM University of Management and Economics, Nagoya University of Commerce and Business, Japan, and Instituto Portugues de Administracao de Marketing (IPAM), Portugal. Prof. Škudienè has presented her research at international conferences in France, Japan, Israel, US (Hawaii, Chicago), Greece, Croatia, France, Spain, Norway, Jamaica, Sweden, Italy (Boccioni), and published over 30 articles, e-textbook on Organizational Behaviour, and co-authored two books on case writing. Prof. Škudiene is a member of editorial advisory board of Baltic Journal of Management. E-mail: vidsku@ism.lt

Dr. Everhart is the owner of eStratOp.com working with businesses, local governments and individuals to improve personal and organizational performance. Using relevant examples from current clients, Dallas's teaching style is interactive and requires student participation to develop critical thinking skills. His work experience demonstrates the importance of communications and teamwork as he has risen to executive position including Finance Director at the City of Aspen, City Manager in Silverthorne, Colorado and Executive Director of Continuing Education at Colorado State University. Dallas dedicates about $25 \%$ of his time to teaching and continues to grow his business developing strategic operating plans. E-mail: Dallas.Everhart@unco.edu

Karolina Šlepikaitė holds a Master degree in International Marketing Management from ISM University of Management and Economics, Lithuania. For four years she has been working in Nordea Bank, Lithuania. In the position of Call Center team leader Karolina has the opportunity to use in practice the knowledge acquired during the studies at university and research experience. The main responsibility of this position is to optimize the work process, motivate team in achieving sales targets, organize daily work and collaborate with other units in preparation of sales projects, as well as arrange trainings on products and sales for the bank employees.

Dr. Reardon is the Chairperson and Professor of Marketing at the Monfort College of Business. His publications have appeared in the Journal of Marketing, Journal of Retailing, Journal of International Marketing, Journal of Marketing Education, among others. He was named the UNC Distinguished Scholar and has been named the Monfort College Scholar five times. In addition, he has been named marketing professor of the year three times. His non-academic background includes managing several businesses in various functions in the Home Shopping, Construction, Casino, and Film industries. E-mail: James.reardon@unco.edu (Corresponding author)

\section{REFERENCES}

1. Anderson, J.C., Narus, J.A. (1998), Business marketing: understand what customers' value, Harvard Business review, November-December, pp. 5-15.

2. Anderson, E.W., Fornell, C., Rust, R.T. (1997), Customer satisfaction, productivity, and profitability: differences between goods and services, Marketing Science, Vol. 16, No. 2, pp. 129-45. 
3. Barnes, J.G, Howlett, D.M. (1998), Predictors of equity in relationships between financial services providers and retail customers, International Journal of Bank Marketing, Vol. 16, Iss: 1, pp. 15 - 23.

4. Bowers, M.R., Martin, C.L., Luker, A. (1990), Trading places: employees as customers, customers as employees, Journal of Services Marketing, Vol. 4, No. 2, pp. 55-69.

5. Carter, J.D.T (2009), Managers Empowering Employees, American Journal of Economics and Business Administration 1(2) 39-44.

6. Christopher, L. (2001), Services Marketing. New Jersey: Pearson Education (4th ed.).

7. Cook, S., Macaulay, S. (1996), Empowered customer service Training for Quality, Journal of Human Resources in Hospitality \& Tourism Vol. 4, pp. 7-11.

8. Conger, J.A., Kanungo, R.N., (1988), The Empowerment Process: Integrating Theory and Practice, Academy of Management Review, 13(3), 471- 482.

9. Cronin J., Michael K. B., Hult, G. (2000), Assessing the Effects of Quality, Value, and Customer Satisfaction on Consumer Behavioral Intentions in Service Environments, Journal of Retailing, Vol. 76, Number 2, Page 193, 2000.

10. Honold, L. (1997), A review of the literature on employee empowerment, Empowerment in Organisations, Vol. 5, No. 4, pp. 202-12.

11. Hopkins, H. (1995), A challenge to managers: five ways to improve employee morale, Executive Development, Vol. 8, No. 7.

12. Johnson, P.R. (1994), Brains, heart and courage: keys to empowerment and self-directed leadership, Journal of Managerial Psychology, Vol. 9, No. 2, pp. 17-21.

13. Lee, M., Koh, J. (2001), Is empowerment really a new concept? International Journal of Human Resource Management, Vol. 12, No. 4, pp. 684-95.

14. London C., Higgot K. (1997), An employee rewardand recognition process, Vol. 9, Number 5, pp. 328335.

15. Loveman, G.W. (1998), Employee satisfaction, customer loyalty, and financial performance: an empirical examination of the service profit chain in retail banking, Journal of Service Research, Vol. 1, No. 1, pp. 1831.

16. Luthans, K. (2000), Recognition: A Powerful bus often Overlooked Leadership Tool to Improve employee performance, The journal of leadership studies Vol. 7, No.1.

17. Marx, M. (1995), Keeping your best employees, Journal of PropertyManagement, pp. $26-29$.

18. McDougall, G. H. G., Levesque, T. (2000), Customer satisfaction with services: putting perceived value into the equation, Journal of Services Marketing Vol. 14, 392-410.

19. Mullins, L.J., Peacock, A. (1991), Managing through people: regulating the employment relationship, Administrator, December, pp. 45-55.

20. Nelson, B. (2001), Make Reinforcement a Positive Experience. Retrieved February 2012 from: http://www.bizjournals.com/extraedge/consultants/return_on_people/2001/08/20/column144.html.

21. Pastor, J. (1996), Empowerment: what it is and what it is not, Empowerment in Organisations, Vol. 4, No. 2, pp. 5-7.

22. Peterson, R.A. (1995), Relationship marketing and the consumer, Journal of the Academy of Marketing Science, Vol. 23, No. 4, pp. 278-81.

23. Petrick, J. F. (2004), The roles of quality, value and satisfaction in predicting cruise passengers' behavioral intentions, Journal of travel research Vol. 42, 397-407.

24. Ramani, G., Kumar, V. (2008), Interaction orientation and firm performance, Journal of Marketing, Vol. 72, No. 1, pp. 27-45.

25. Roig, J. C. F. (2006), Customer perceived value in banking services, International Journal of Bank Marketing, Vol. 24, Number 5, Pages 266-283.

26. Saunders, M., Lewis, P., Thornhill, A. (2007) Research methods for business students (4th. Ed). Pearson Education- England.

27. Saunderson, R. (2004), Survey Findings of the Effectiveness of Employee Recognition in the Public Sector, Public Personnel Management, 33, 3, 255-276.

28. Samad, S. (2007), Social Structural Characteristics and Employee Empowerment: The Role of Proactive Personality, International Review of Business Research Papers Vol. 3, No.4, Pp. 254-264.

29. Sawhney, M., Kotler, P. (2001), Marketing in the age of information democracy, Kellogg on Marketing, Wiley, New York, NY, pp. 386-409.3 
30. Sheth, J. N., Newman B.I., Gross, B.L. (1991), Why We Buy What We Buy: A Theory of Consumption Values, Journal of Business Research, Vol. 22, Number 2, Pages 159-170.

31. Spreitzer, G.M. (1995), Individual empowerment in the workplace: Dimensions, measurement and validation, Academy of Management Journal, Vol. 38, pp. 1442-1465.

32. Thomas, K. W., Velthouse, B. A. (1990), Cognitive elements of empowerment: An interpretive model of intrinsic task motivation, Academy of Management Review, 15, 666-681.

33. Wilkinson, A. (1998), Empowerment: theory and practice, Review, Vol. 27, No. 1, pp. 40-56. 